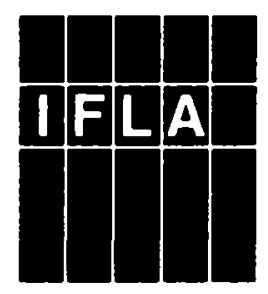


International Federation of Library Associations and Institutions Fédération Internationale des Associations de Bibliothécaires et des Bibliothèques Internationaler Verband der bibliothekarischen Vereine und Institutionen Меххународная Федерация Библиотечньх Ассошнащиі и Учреждення 
IFLA Publications 30

\section{A Guide to Developing Braille and Talking Book Services}

Edited by Leslie L. Clark in collaboration with Dina N. Bedi and John M. Gill

K.G.Saur München · NewYork · London · Paris 1984 


\section{IFLA Publications edited by Willem R. H. Koops}

Recommended catalog entry:

Clark, Leslie L.

A Guide to Developing Braille and Talking Book Services /

by Lestie L. Clark. - München.

New York etc.: K. G. Saur 1984. 108 p.; $21 \mathrm{~cm}$. -

(IFLA Publications; 30)

ISBN 3-598-20395-0

CIP-Kurztitelaufnahme der Deutschen Bibliothek

Clark, Leslie L.:

A guide to developing Braille and talking book services / ed. by Leslie L. Clark in collab. with Dina N. Bedi and John M. Gill. [Internat. Fed. of Library Assoc. and Inst.]. - München ; New York ; London ; Paris: Saur, 1984.

(IFLA publications ; 30 )

ISBN 3-598-20395-0

NE: International Federation of Library Associations and Institutions: IF LA publications; HST

ISSN 0344-6891 (IFLA publications)

(C) 1984 by International Federation of Library Associations and Institutions The Hague, The Netherlands Printed and bound in the Federal Republic of Germany for K. G. Saur Verlag KG, München by Hain-Druck $\mathrm{GmbH}$, Meisenheim/Glan by Thomas Buchbinderei, Augsburg

All rights reserved. No part of this publication may be reproduced, stored in a retrieval system or transmitted in any form or by any means, electronic mechanical, photocopying, recording, or otherwise, without permission in writing from the publisher.

ISBN 3-598-20395-0 